\title{
Howard Goldblatt's Translations of Mo Yan's Works into English: Reader Oriented Approach
}

NISHIT KUMAR

\begin{abstract}
This article examines the strategies followed by Howard Goldblatt, the official translator of Mo Yan while translating his works from Chinese into English. Mo Yan was awarded the Nobel Prize in Literature in 2012 and critics argued that it was Goldblatt's translation that was mainly responsible for Mo Yan's Nobel Prize in Literature. Though Mo Yan's works in translation are available in various languages, it is Goldblatt's version that has become most popular. Therefore, from the perspective of Translation Studies, it would be interesting to identify the techniques used by Goldblatt that make his translations so special. The present paper compares titles, structure, and culture-specific expressions in the original and its English translation to identify the strategies followed by Howard Goldblatt in translating Chinese literary texts.
\end{abstract}

Keywords: Mo Yan, Howard Goldblatt, Chinese literature, Translation strategies.

\section{Introduction}

As an ancient civilization, China has rich literature spanning several millennia, touching upon a wide range of literary genres enriched by numerous creative writers. However, until the 1980s, modern Chinese literature was vastly underrepresented within the purview of world literature and did not gain significant readership in other parts of the world. As a result, China has been seeking international recognition for its vast body of literature. The Chinese authors have been making an effort for the Nobel Prize in Literature from as far back as the 1940s. The failure and anxiety of not being awarded the Nobel Prize in Literature led to an obsession in China, which 
Lovell (2006: 2) has termed as 'Nobel Complex.' It is wellknown that since its inception, it has been chiefly the authors writing in European languages who bagged the Nobel Prize in Literature. To date, the award went to 117 laureates on 113 occasions, and among them, writers writing in English were 30 , French was 15 , German was 14, Spanish was 11, Italian was 6, Polish was 5, Norwegian and Danish were three each. Only nine Non-Euro-American writers have received the Nobel Prize, along with six Russian writers. As a result, the Swedish Academy, the awarding institution of the Nobel Prize in Literature, has often been reproached for making the award a Euro-American-centric affair. In the background of this international scenario, when the Nobel Prize in Literature 2012 went to the Chinese writer Mo Yan, it became a matter of joy and jubilation. His work showcased hallucinatory realism in which he mixed folk stories, folk songs, and history with contemporary issues. This paper has tried to identify some of the translation strategies used by Howard Goldblatt in his rendering of Mo Yan's works. The idea is to understand Goldblatt's translation strategies better, which will be beneficial to future translators in enhancing their translation and making it a more enriching exercise.

\section{Translation Strategies}

There are two fundamental translation strategies, i.e., Domestication and Foreignization (as proposed by Venuti 1995). These two approaches give directions to the translators of literary texts in terms of their linguistic and cultural background. Lawrence Venuti would suggest that domestication here stood for 'an ethnocentric bargain of cultural values' from the foreign text while translating into the target language. In comparison, foreignization refers to 'an ethnic-deviant pressure on those (cultural) values to register the linguistic and cultural difference of the foreign text, 
Howard Goldblatt's Translations of Mo Yan's Works into English:...

sending the reader abroad.' (Durin 1995: 20). While domestication does not automatically guarantee passing on the cultural and linguistic values of a foreign language (for various reasons), foreignization imports the cultural and linguistic values of a foreign language. However, debates over both strategies have been constant. Their differences and dispute as contrasting techniques have a cultural and political bias. It is surely not a linguistic contrast; in that, it is not a replay of the free translation and literal translation debate (Dongfeng 2002: 24). Founder of modern discipline 'dynamic equivalence' and 'formal equivalence' in Translation Studies, Eugene A. Nida, pointed out that biculturalism was even more critical for truly successful translation than bilingualism. Nida's point was that words are carriers of meanings only because of the cultures in which they are used (Cf. Macksey \& Dil 1975: 82).

For cultural translation, Venuti has maintained that the English language and the Anglo-American culture together dominate globally. The complacency they provide in relation to other cultures can be 'described as imperialistic abroad and xenophobic at home' (Durin 1995:17). If culture is considered capital, we could see a disparity in its export and import. This disparity shrinks the cultural capital of foreign values in English by restraining the number of imported texts that are translated and then yielding them to changes suitable for domestication. As a result, English translators are more inclined towards using the strategy of domestication. Sun Zhili suggested - based on his own experience as a translator - that the translation of Chinese literature should use more foreignization to transmit different elements of the original text with greater accuracy and effectiveness (Zhili 2002: 41). In other words, one needs to consider the cultural characteristics of a nation, language diversity, and the various methods of writing used by the authors. However, other Chinese scholars advocated in favour of the domestication strategy. 


\section{Howard Goldblatt's Strategies}

Howard Goldblatt is the official translator of Mo Yan and has translated almost all of his significant works. Goldblatt not only promoted Mo Yan's works, but he was also an important reason for Mo Yan receiving the Nobel Prize. Although Mo Yan's works are available in translation in various languages, it is Goldblatt's version that has become most popular and established Mo Yan in the western literary World. Therefore, from the perspective of translation studies, it would be interesting to identify the techniques used by Goldblatt that make his translations so special. As one compares the titles, structure, cultural terms, and sayings in the Chinese and English versions, one could see that he used domestication, foreignization, sometimes both, sometimes none, and sometimes more than that.

\section{Translating Titles}

The title of a novel is one of the most critical components of translating literary texts, as it conveys the essence of the literary work at hand. While translating a title, Goldblatt used different strategies for different titles. Appendix 1 provides a list of Mo Yan's works translated by Howard Goldblatt.

First on the list is the famous novel, Honggaoliang jiazu (红高粱家族), which happens to be his first novel that Goldblatt lay his hands on. The literal rendering of Honggaoliang jiazu is the Red Sorghum Family; however, Goldblatt renamed it as Red Sorghum: A Novel of China. He translated it in the early 1990s when publishing foreign literature in translation was still not a viable commercial proposition. Thus, this additional phrase 'a novel of China' was likely to have attracted literature enthusiasts who wanted to understand China. The very next work he translated was Tiantang suantai zhi ge (天堂蒜臺之歌). He called it The 
Garlic Ballads. Tiantang means heaven, suantai is garlic, and ge is a song or ballad. Goldblatt omitted the meaning of Tiantang from its title in translation. These choices have to do with the story where a mad person sang the ballad. Another work, Jiu Guo (酒国) became the Republic of Wine. Here, Jiu stood for 'alcohol', and guo referred to 'country'. The selection of the word 'republic' reflects the political intervention of an American translator. He translated another title, Shifu, yue lai yue youmo (师傅 越来越幽默), as Shifu, You'll Do Anything for a Laugh. The literal translation of Shifu, yue lai yue youmo is Master, More and More Humorous. In this title, Goldblatt left 'shifu' as it is and changed the other part of the title according to the context of the story and for the readers of English. Here, he first used foreignization and then the strategy of cultural translation. Mo Yan's most controversial work titled Fengru feitun (丰乳肥臀) had an interesting journey. Goldblatt decided to be literal here. He called it Big Breasts and Wide Hips, because Fengru literally means 'big breasts', and feitun means 'wide hips'. Here, the translator did not indulge in either foreignization or domestication. Goldblatt translated Sishiyi pao (四十一炮) as Pow! The literal translation of Sishiyi pao would be forty-one cannon. But Goldblatt used the context of the story and reduced the title to one word, which represented the sound of cannon. While translating some of the other titles, Goldblatt translated it, for instance, Wa (蛙) as Frog, Touming de hong luobo (透明的红夢卜) as The Crystal Carrot, Bian (变) as Change, etc. Besides translating titles, Goldblatt used several mixed strategies in recreating the text in English: Addition, Omission, Modification, Domestication, and Foreignization.

\section{Structural Modifications}

As mentioned in the earlier section, the first fiction of Mo Yan, Honggaoliang jiazu became Red Sorghum: A Novel of China 
in 1993. It was already a famous work in China, and Zhang Yimou's debut movie was based on this novel, which won the Golden Bear Award in Germany. Howard Goldblatt's translation of Red Sorghum did not follow the same structure as the original Chinese version. He altered it significantly, which may be regarded as a serious issue as far as the fidelity of the text was concerned. He restructured the original, and instead of presenting it in nine chapters, he reduced it to five. Along with this, he added sub-titles in these chapters. After reading the whole text, Howard Goldblatt consulted with Mo Yan and asked him to rewrite the ending of the original Chinese novel. That was how it became very different in Howard Goldblatt's version. In addition, changes had to meet the aesthetic demand and prevailing political mindset of the West. For instance, while translating The Garlic Ballads, Goldblatt rendered these Chinese sentences “仲县长你手安心窝存细想.....你到底入的是什么党.... 你要是国民党就高枕安睡.....你要是共产堂鸣鼓出堂” as “County Boss Zhong, put your hand over your heart.... think as government protector, where is the kindness in your soul.... If you are a benighted official, go home and stay in bed...... If you are an upright steward, take charge and do some good" instead of its literal meaning, "County Boss Zhong, put your hand on your heart.... think, What Party are you in?... If it's the Kuomintang, you can sleep tight......If it's the Communist Party, you should give a command and go to the court...."1.

Howard Goldblatt omitted unusual descriptions like nostalgia, flashback, and some unimportant details of the plots (Deng \& Zhang 2017: 50-53). For a deeper understanding of Howard Goldblatt's translations, Y. Zhang researched Goldblatt's translation strategy by exploring several dialectal expressions from Mo Yan's The Garlic Ballads. As a result, he concluded

\footnotetext{
${ }^{1}$ Chinese to English translation is done by Nishit Kumar.
} 
that Howard Goldblatt's translation strategy involved reading in Chinese and writing in English. In other words, recreating the Chinese source texts into target texts in English was his dominant translating strategy (Zhang 2005). For example, Jinyue Wang, while comparing the Chinese and English versions of Shengsi pilao (生死疲劳 Life and Death is wearing me out), found that more than 40 pages or approximately 30,000 Chinese words of the original got omitted (Wang 2019).

\section{Culture-Specific Expressions}

In order to show how Goldblatt handled culture-specific expressions from Chinese to English, Linguist Yongmei Jiang explored one of Mo Yan's representative works, Big Breasts, and Wide Hips; she looked at culture-specific expressions ranging from material culture to social culture to religious culture. For instance, Howard Goldblatt translated 灵芝草 (lingzhi cao) as 'grass of miracle', 门槛 (menkan) as 'door way', 大恩大德 (da en da de) as' in his debt', 神(shen) as 'an eminent personage', 十八辈子祖宗 (shiba beizi zuzong) as 'the eighteen generations of women'. In conclusion, Jiang stated that Howard Goldblatt's opted for literal translation and domestication. His decision to go for alteration and omission made the text more palatable to the readers of the target language. "If the translator alters or modifies the original text and culture without restraint and only caters to target language readers and critics, merely to secure business success, he then betrays the original work and at the same time deceives the reader. Therefore this translation couldn't be regarded as good translation." (Jiang 2015: 1290). Another comparison of Goldblatt's translation of culture-specific expressions has been selected by L. Shao from Life and Death Are Wearing Me Out; in his research, he found that Howard Goldblatt implied [对文化负载词进行删减（或曰文化调适法）与“字面忠实” 
（即所谓“伪忠实”）表面上看似矛盾，但在同一译本中， 这两方面的确都是葛浩文的译者风格.]. Here, his argument was that Goldblatt used 'two methods to reproduce the information contained in the source texts.' One could easily see the use of 'cultural modulation (including omission) and pseudo-fidelity (literal translation)'2 (Shao 2013: 64). Jinyue Wang analysed the translation of Chinese proverbs as in Goldblatt's Life and Death Are Wearing Me Out in terms of Newmark's five translation methods. Wang (2019: 19), concluded by saying: 'Howard Goldblatt's literal translations could be either accurate or inaccurate; omissions could make the original cultural images inaccessible to English readers; adaptations could only deliver part of the original meanings to English readers; faithful translations can carry the full meaning of the source text but hard to precisely preserve the original form and content completely; both semantic and communicative translations can be functionally equivalent to their source texts and easier to read.' In the study of idiom translations, Wang and Mei noted that Howard Goldblatt choose word-for-word translation for linguistic dimension; word-for-word translation or free translation for cultural dimension and rewriting for communicative dimension (Wang \& Mei 2014:102).

\section{Conclusion}

The reader was Howard Goldblatt's priority while translating Mo Yan's works. He reorganized the entire novel, keeping in mind the Western-Anglophone readers' reading habits and aesthetics. He added and omitted certain characters and scenes from Mo Yan's novels to fit into the political mindset of the West and restrict readers from indulging in unnecessary information. It not only took away the added load but also

\footnotetext{
${ }^{2}$ Chinese to English translation is done by Nishit Kumar.
} 
made the work more coherent for the reader. One could call it a 'reader-oriented translation' ${ }^{3}$. However, in this context, it is important to note that Howard Goldblatt was also not betraying the author, as Mo Yan completely agreed with his choice of alteration and provided him total rights to make whatever alterations he wished to. Although there was a loss of specifics, it is more conversant and gracious for the readers of the translated text. One could call it a prerequisite for literature and culture to go beyond its indigenous borders and for circulation in target languages. Thus, drawing from the above examples, it can be said that Howard Goldblatt consciously rewrote the linguistic features and cultural images while translating Chinese literature into English so as to create suitable and understandable literature for his readers.

Acknowledgement: This work was outlined during doctoral studies at Jawaharlal Nehru University. The initial text was written during a Visiting Fellowship at the Harvard University in 2019-2020 and was supported by Harvard-Yenching Institute (HYI), Boston, and Institute of Chinese Studies (ICS), New Delhi.

Notes: 1. Mo Yan (1955- ): The Chinese writer Guan Moye uses 'Mo Yan' as his pen name. He was born in Ping'an Zhuang village of Northeast Gaomi, People's Republic of China (PRC) on 17th February 1955 in a peasant family. He dropped out of primary school in the 5th grade during the Cultural Revolution (1966-1976). Over a period of time, he started creating multiple literary genres, such as short stories, novels, and essays. He published Hong gao liang jiazu (The

${ }^{3}$ Here, I am borrowing the term 'Reader-oriented' from the reception studies. It has been tried to summarize Goldblatt's translation strategies as 'reader-oriented', meaning a source text is being translated into target text in which the style and structure has been subordinated to the needs of the reader rather than to those of writer. 
Red Sorghum) in 1986 followed by these novels in the following years: Tiantang suantai zhi ge (The Garlic Ballads, 1988), Shisan bu (Thirteen Steps, 1989), Jiu guo (The Republic of Wine, 1992), Fengru feitun (Big Breasts and Wide Hips, 1992). He has written 11 novels, 30 novellas, more than 80 short stories, plays, and prose collections. Mo Yan became popular through Zhang Yimou's film Red Shorgum (1987), based on his novel by the same name Hong gaoliang jiazu (1986). Over time, his narrative style experimented with new techniques. It is now well accepted that the hallmark of Mo Yan's writing is that he combined written literary style with popular oral traditions to describe and comment on contemporary issues that have a connection with Chinese society and culture. Mo Yan's works have been translated into more than 52 languages so far. His works first reached outside the national boundary to Japan. However, it is the translation of a foreign work in the world's lingua franca, i.e., English, that pre-dominantly decided its stature in World Literature.

2. Howard Goldblatt (1939- ) - Howard Goldblatt is one of America's most prolific and influential translators. $\mathrm{He}$ is a scholar, professor, author, and translator of modern and contemporary Chinese literature. He was born in 1939, and he joined the US Navy, during which time he was posted in Taiwan. There, he had an introduction to the Chinese language and culture. Later, he shared this knowledge with many Anglophone readers through his translations and teachings. John Updike thought that by translating these contemporary Chinese novels for the American readership, Howard Goldblatt has established it as his "lonely province". In addition to his role as translator and academician, he was also one of the founding editors of the academic journal Modern Chinese Literature. Howard Goldblatt was not the first one to translate Mo Yan's works in English. Other translators, such as Michael Duke, Janice Wickeri, Christopher Smith, Mei Zhong, Yu 
Howard Goldblatt's Translations of Mo Yan's Works into English:...

Fanqin, and Jeanne Tai, translated Mo Yan's work even before Howard Goldblatt did. However, Mo Yan designated him as the official translator of his works, and he went on to become also the most famous one. He has translated almost all major works of Mo Yan, for example, Red Sorghum, The Garlic Ballads, The Republic of Wine, Big Breasts and Wide Hips, Sandalwood Death, and Frog, etc.

Appendix 1. A list of Goldblatt's translation of Mo Yan:

\begin{tabular}{|c|c|c|c|c|}
\hline $\begin{array}{l}\text { S. } \\
\text { No. }\end{array}$ & Chinese Name & English Name & Publishers & Year \\
\hline 1 & $\begin{array}{c}\text { 《红高粱家族》 } \\
\text { Hong gao liang jiazu }\end{array}$ & $\begin{array}{l}\text { Red Sorghum: A } \\
\text { Novel of China }\end{array}$ & Arcade & 1993 \\
\hline 3 & $\begin{array}{c}\text { 《天堂赫薹之歌》 } \\
\text { Tiantang suantai ge }\end{array}$ & $\begin{array}{l}\text { The Garlic } \\
\text { Ballads }\end{array}$ & $\begin{array}{l}\text { Penguin } \\
\text { Books }\end{array}$ & 1995 \\
\hline 4 & $\begin{array}{l}\text { 《酒国》 } \\
\text { Jiu guo }\end{array}$ & $\begin{array}{l}\text { The Republic of } \\
\text { Wine }\end{array}$ & Arcade & 2000 \\
\hline 5 & $\begin{array}{l}\text { 《师傅越来越幽默》 } \\
\text { Shifu, yue lai yue youmo }\end{array}$ & $\begin{array}{l}\text { Shifu, You'll Do } \\
\text { Anything for a } \\
\text { Laugh }\end{array}$ & Arcade & 2001 \\
\hline 6 & $\begin{array}{l}\text { 《丰乳肥殿》 } \\
\text { Fengru feitun }\end{array}$ & $\begin{array}{l}\text { Big Breasts and } \\
\text { Wide Hips }\end{array}$ & Arcade & 2004 \\
\hline 7 & $\begin{array}{l}\text { 《生死疲劳》 } \\
\text { Shengsi pilao }\end{array}$ & $\begin{array}{l}\text { Life and Death } \\
\text { Are Wearing Me } \\
\text { Out }\end{array}$ & Arcade & 2008 \\
\hline 8 & $\begin{array}{l}\text { 《变》 } \\
\text { Bian }\end{array}$ & Change & Seagull & 2010 \\
\hline 9 & $\begin{array}{l}\text { 《四十一炮》 } \\
\text { Sishiyi pao }\end{array}$ & Pow! & Seagull & 2010 \\
\hline \multirow[t]{2}{*}{10} & \multirow[t]{2}{*}{$\begin{array}{l}\text { 《檀香刑》 } \\
\text { Tangxiang xing }\end{array}$} & \multirow[t]{2}{*}{$\begin{array}{l}\text { Sandalwood } \\
\text { Death }\end{array}$} & $\begin{array}{l}\text { Chinese } \\
\text { Literature } \\
\text { Today }\end{array}$ & 2012 \\
\hline & & & $\begin{array}{l}\text { Granta } \\
\text { Magazine }\end{array}$ & 2012 \\
\hline
\end{tabular}


Nishit Kumar

\begin{tabular}{|c|l|l|l|l|}
\hline 11 & $\begin{array}{l}\text { 《蛙》 } \\
\text { Wa }\end{array}$ & Frog & $\begin{array}{l}\text { Viking, } \\
\text { Penguin, } \\
\text { Hamish } \\
\text { Hamilton }\end{array}$ & 2015, \\
2016 \\
\hline 12 & $\begin{array}{l}\text { 《透明的红萝卜》 } \\
\text { Touming de hong luobo }\end{array}$ & The Crystal carrot & Penguin & 2015 \\
\hline
\end{tabular}

\section{References}

Deng, W., \& Zhang, K. 2017. Howard Goldblatt's Three Treaties or Treatments of Translation. Theory and Practice in Language Studies, 7(1). 49-54. https://doi.org/10.17507/tpls.0701.06

Dongfeng, W. 2002. Domestication and Foreignization: a Contradiction? China Translation, 9. 24-26.

Durin, C. 1995. Review of [Lawrence Venuti. The Translator's Invisibility. A History of Translation. London and New York: Routledge, coll. «Translation Studies », 1995, 353 pages]. TTR : Traduction, Terminologie, Rédaction, 8(2). https://doi.org/10.7202/037229ar

Jiang, Y. 2015. The Globalization of Chinese Culture and Goldblatt's Translation of Chinese Literature-A Case Study of Big Breasts and Wide Hips. Theory and Practice in Language Studies, 5(6).1286-1290. https://doi.org/10.17507/tpls.0506.23

Lovell, J. 2006. The Politics of Cultural Capital: China's Quest for a Nobel Prize in Literature (First Edition). Hawaii: University of Hawaii Press.

Macksey, R., \& A. S. Dil. 1975. Language Structure and Translation: Essays by Eugene A. Nida. MLN, 90(6). 731737. https://doi.org/10.2307/2907038

Shao，L. (2013. 莫言英译者葛浩文翻译中的 “忠实”与 “伪忠实” (Fidelity and Pseudofidelity of Howard Goldblatt's Translation of Mo Yan's Novels. 中国翻译 (Chinese Translators Journal), 3. 62-67. 
Howard Goldblatt's Translations of Mo Yan's Works into English:...

Wang, J. 2019. Translating and Rewriting Chinese Proverbs: A Case Study of Howard Goldblatt's English Translation of Mo Yan's "Shengsi Pilao." English Language and Literature Studies, 9(2).12-24. https://doi.org/10.5539/ells.v9n2p12.

Jiang, Y. 2015. The Globalization of Chinese Culture and Howard Goldblatt's Translation of Chinese Literature- a Case Study of Big Breasts and Wide Hips. Theory and Practice in Language Studies, 5(6).1286-1290. http://dx.doi.org/10.17507/tpls.0506.23.

Venuti, Lawrence. 1995. The Translator's Invisibility: A History of Translation. London \& New York: Routledge. Yiting, W., \& $\quad$ Mei, L. 2014. 翻译适应选择论视角下《生死疲劳》的习语翻译（Idio $\mathrm{m}$ Translation in Mo Yan's Life and Death are Wearing Me Out: From the Perspective of Translation as Adaptation and Selection），（常州大学学报(社会科学版)）Journal of Changzhou University (Social Science Edition), 15(4).100102. https://doi:10. 3969 /j. issn.2095-042X.2014.04.022 Zhang., Y. 2005. 拿汉语读,用英文写一一说说葛浩文的翻译 (Howard Goldblatt: To read in Chinese and to write in English). 中国翻译 (Chinese Translators Journal), 2. 75-77. Zhili, S. 2002. 中国的文学翻译: 从归化趋向异化 (China's Literature Translation: from Domestication to Foreignization). 中国翻译 (Chinese Translator's Journal), 1. 39-43.

$* * *$

\section{Cite This Work:}

KUMAR, NISHIT . 2021. Howard Goldblatt's Translations of Mo Yan's Works into English: Reader Oriented Approach. Translation Today, Vol. 15(1). 207-219. DOI:10.46623/tt/2021.15.1.no4 